\title{
European solidarity as boundary-making: A conjoint analysis of attitudes towards Islam in the context of the 'refugee crisis'
}

Journal of Sociology 202I, Vol. 57(2) 305-324

(C) The Author(s) 2020

Article reuse guidelines: sagepub.com/journals-permissions DOI: 10.1 I 177/I440783320902945 journals.sagepub.com/home/jos

@SAGE

\author{
Lukasz Krzyzowski \\ AGH University of Science and Technology, Poland
}

\section{Magdalena Nowicka}

Humboldt-Universität zu Berlin, Germany

\begin{abstract}
The arrival of refugees from predominantly Muslim countries in the core of Europe has fuelled discussions on European solidarity. This article explores the sources of solidarity in Europe in the aftermath of the 'refugee crisis' of 2015. By focusing on migrants' attitudes towards refugees, the article considers solidarity in light of contradictory public discourses on refugees in Europe. Drawing on data from a survey among Polish migrants residing in Germany and applying a conjoint analysis, the article demonstrates that religion and gender are the main criteria for boundary-making between the respondents and the refugees. In this process, national and ethnic identities are subordinated to the idea of belonging to an imagined Christian community. Our results suggest that new exclusionary solidarities shaped by boundary-making between Christians and Muslim refugees are being established within Europe. As a result, Islamophobia emerges as a transnational European exclusionary project evading ethnic and national boundaries.
\end{abstract}

\section{Keywords}

boundary-making, conjoint analysis, East European migrants, Islamophobia, 'refugee crisis'

\footnotetext{
Corresponding author:

Lukasz Krzyzowski, Department of Sociology and Social Anthropology, AGH University of Science and Technology, Ul. Gramatyka 8a, Kraków, 30-07I, Poland.

Email: lukasz.krzyzowski@agh.edu.pl
} 
As UN Secretary-General Ban Ki-moon noted, in a speech he gave in Washington, DC in April 2016, the 'refugee crisis' is about solidarity, not just numbers. He concluded by saying that European societies today more than ever need to respond with 'monumental solidarity' (Ban Ki-moon, 2016). Europe seems far away from this goal for at least two reasons. First, the disparate positions of the European Union (EU) member states on the question of the relocation of refugees across Europe that manifest in the revival of alliances between certain countries (e.g. Visegrad Group, Three Sees Initiative) ${ }^{1}$ have demonstrated the fragility of the EU's political unity (Kymlicka, 2015; Oosterlynck et al., 2016). Second, the rapid and large-scale immigration of predominantly non-European and non-Christian immigrants has raised concerns in relation to Europe's core values such as respect for equality and democracy, considered the source of European solidarity (Ariely, 2014). This article focuses on these challenges and asks: what are the sources of European solidarity with refugees?

Solidarity is one of the most central concepts in the social sciences but it remains largely unclear what the sources of solidarity are (Banting and Kymlicka, 2017; Baurmann, 1999). The shift from mechanical to organic solidarity in the course of industrialization, as put forth by Durkheim (1997), was associated with two types of collectivity - the first based on common cultural values, and the second being more complex or diversified, relying on the division of labour and the interdependence of individuals. Various authors argue that modern national solidarity, in fact, combines both types, cultural and civic solidarity (Calhoun, 1999; Oosterlynck et al., 2016). Others stress that the nation-state has successfully replaced the particularistic solidarity of religious or ethnic communities (Münch, 2012), or - contrarily - that due to globalization, common cultural values are gaining even more importance as a source of solidarity, both at the national and European level (Tiryakian, 2005).

Elsewhere, we argued that a distinctively transnational, European model of solidarity is missing from social theory (Nowicka et al., 2019). Instead, the national model of solidarity is often imposed on Europe, while some? scholars, pursuing a vision of civic cosmopolitan (instead of cultural: ethnic or national) underpinnings of European solidarity, point to the Charter of Fundamental Rights of Europe that exemplifies the European integration paradigm. The charter relies on references to civic values: respect for human dignity; liberty; democracy; equality; the rule of law and respect for human rights, including the rights of persons belonging to minorities (Delanty, 2007). This understanding entails cosmopolitan elements (Pensky, 2000), but it does not necessarily replace particularistic, ethnic, cultural or religious belongings and exclusive solidarities (Gould, 2011).

Importantly, any strengthening of solidarity with reference to shared values - both cultural and civic - goes hand in hand with an ambiguous relationship with the group's perceived others (Alexander, 2014). Thus, cosmopolitan stances that regard embracing the differences within a society as the path to solidarity (Vasta, 2010) go hand in hand with fear of refugees who threaten these values and thus European solidarity (Bansak et al., 2016). But rejecting refugees out of a fear of losing core values contradicts these very cosmopolitan values, and poses a moral dilemma for the Europeans and, currently, a challenge to European solidarity.

This article departs from two overlapping fields of tension sketched above to ask what the sources of European solidarity in the aftermath the 'refugee crisis' are. The first field 
of tension exists between a common European identity and diverging political discourses surrounding refugees, and the second between the particularistic, exclusionary and cosmopolitan underpinnings of solidarity. We believe that these tensions can best be addressed by studying migrants. Working from the assumption that majority populations wield substantial power over solidarity, and acknowledging transnational connections of migrants with their homelands (Waldinger, 2015), we consider that migrants are exposed to potentially contradictory discourses, ideas and norms around belonging and their interpretations in the country of origin and residence. As we elaborate in the article, Poland and Germany constitute two contexts characterized by contradictory approaches towards granting refuge to new asylum seekers. But, as we demonstrated elsewhere, migrants' attitudes are irreducible to national positions and are thus paradigmatic of a European position. Our past research has shown that, with $17 \%$ of Polish migrants in Germany declaring that they have provided voluntary assistance to refugees, this proportion was higher than among Germans (Nowicka et al., 2017), which makes a perfect case for studying the sources of solidarity.

We begin our article with a brief discussion of how the European identity project relies on the othering of Islam and Muslims as those who do not share European values, and how the othering is reflected in EU citizens' attitudes towards Muslim immigrants and refugees. Within this discussion, we dedicate particular attention to Germany and Poland. We will then introduce our survey, in which we studied migrants' attitudes towards different groups of refugees and their actual engagement in assisting refugees in Germany, Poland or elsewhere in Europe. This study used a vignette design. We applied a conjoint analysis to make sense of the collected material. This design was chosen to help establish how respondents value different attributes of refugees (such as religion, gender), which determines their decision as to whether to show solidarity with these groups. In the concluding section, we argue that new exclusionary solidarities shaped by boundary-making between Christians and Muslim refugees are being established within Europe. As a result, Islamophobia seems to be turning into a source for a transnational European exclusionary project that parallels other particularistic and cosmopolitan solidarity patterns.

\section{European solidarity, diversity and Europe's shared 'Other'}

The definition of so-called 'core European values' entered the public discussion as late as 1973, when the Declaration of European Identity was adopted during the Copenhagen Summit by the nine member states of the European Community (EC). The Copenhagen declaration appealed to unity and a common heritage, as well as cultural convergence among the member states (Blokker and Delanty, 2010). Yet, as the EC grew, the 'core European values' were redefined in the 1990s around a new concept of 'unity in diversity' (Castano, 2004). The Charter of Fundamental Rights of Europe, ratified in December 2000, emphasized norms and values shared by all Europeans, but it simultaneously stressed the need to respect the diversity of histories, languages, populations and futures of the old and new member states within the EU. It was hoped that European values, in the absence of a common language and memory, would become a strong foundation for European solidarity (Delanty, 2007). 
Identifying with Europe, and feeling solidarity with it, can also be achieved through the shared 'Other' (Delanty, 1995; Wintle, 2016). Otherness, or othering, is central to collective identity building. While the imaginary of boundaries between the Self and others is descriptive and helps people organize and make sense of the complexity of the world, othering is strategic (Creutz-Kämppi, 2008); it assures power and privilege by establishing exclusive group memberships (Bhabha, 1996; Hall, 1996). But it is strategic in another sense as well: the exclusion of the other constructs one's own group as homogeneous and fosters (restrictive) solidarity within a group, which is entangled with racial prejudice and ethnic stigmatization of the group's outsiders (Alexander, 2014; Diez, 2010).

Said (2003) famously argued that the establishment of a European collective identity rested upon the othering of what was constructed as the 'Orient'. Since the end of the Cold War period, European identity has become based, increasingly, on the othering of Islam as Europe's external enemy (Diez, 2010), but now Islam is Europe's internal rather than external other (El-Tayeb, 2011). Europe's (Muslim) Others are refused cultural commonality and accused of social and cultural backwardness (Runnymede Trust, 1997). Othering of Muslims relies on the supposed historical incompatibility of European and Islamic values (Allen, 2010). At the microlevel, othering encompasses many expressions of prejudice towards Muslims on the basis of group belonging (Balibar, 1991; Semati, 2010). Anti-Muslim attitudes were already widespread in Europe before the 'refugee crisis' (Strabac et al., 2013; Zick et al., 2011). Current Islamophobia relies on the entanglement of the construction of Islam as 'Other' and anti-immigrant attitudes (Bayrakli and Hafez, 2016; Helbling, 2017). In the following, we look more closely at attitudes towards Muslims in Poland and Germany, the two countries with which we are concerned in our study.

\section{Attitudes towards Muslims in Poland and Germany: similarities and differences in the context of the 'refugee crisis'}

The majority of Europeans tend to overestimate the size of the Muslim population in their countries and the negative consequences of the Muslim presence in Europe (Ipsos Mori, 2014). Muslim asylum seekers are less likely to be accepted than otherwise similar Christian asylum seekers in Europe, and this bias is much stronger in Poland than in Germany or in any other surveyed country (Bansak et al., 2016).

Islamophobic images vary between contexts. Comparative European studies on prejudice show that Poland scores higher than the Western European countries surveyed (including Germany) in terms of anti-Muslim and anti-Islam attitudes (Bayrakli and Hafez, 2016). For example, the European Values Survey data from 2014 demonstrate that only $7 \%$ of respondents in Poland would be willing to accept Muslims coming to and living in Europe, compared to $25 \%$ of German respondents (Tausch, 2016). Muslims are perceived predominantly as a symbolic threat (to values, norms, and culture) rather than a real threat (to jobs, security and well-being) to the native population in Germany and in Poland, while the fear that Muslim refugees might misuse welfare state privileges is based on negative ideas of their laziness, dishonesty and perfidiousness (Hall and Mikulska-Jolles, 2016). 
Germany is no exception with regard to Islamophobia (Younes, 2016); 41\% of German respondents would like to forbid further immigration by this group (Decker et al., 2016). By the end of 2015, some 4.7 million Muslims were living in Germany, a quarter of whom had arrived in Germany in the previous five years (Stichs, 2016). Numerous studies demonstrate how Islamophobic rhetoric functions in German media, politics and everyday discourses (Bielefeld 2010; Klug, 2010; Ruf, 2012; Zick and Klein, 2014). The PEGIDA (Patriotic Europeans Against the Islamization of the Occident) movement as well as the right-wing party AfD (Alternative for Germany) repeat Islamophobic arguments at their public events and in their speeches and documents (Çakir, 2016).

While the sources of Islamophobia in Germany and Poland are common to some degree, Poland's Islamophobia exists despite the absence of a large Muslim community (Buchowski, 2016; Górak-Sosnowska, 2016). Expert estimates indicate that around 35,000 adherents of Islam live in Poland today, which is less than $0.1 \%$ of the total population. The fear of Islam in Poland relies on stereotypes and stigmatization rather than everyday interactions, and is rooted in an uncritical adoption of Western attitudinal patterns (Narkowicz and Pędziwiatr, 2017; Pickel and Özturk, 2018).

Negative opinions about Muslims are reflected in surveys on the attitudes of Poles towards refugees. ${ }^{2}$ In early 2016 , only $4 \%$ of Polish respondents were willing to accept refugees from the Middle East and Africa in Poland, while 55\% were ready to accept refugees from Ukraine (CBOS, 2016). By contrast, 69\% of Germans were willing to accept refugees in general, and of these, fewer respondents $(51 \%)$ were ready to accept Muslim refugees rather than Christian (72\%), and only $31 \%$ would clearly reject Muslim refugees in Germany (Gerhards et al., 2016). Fewer people in Poland than in Germany support the fair distribution of asylum seekers among all the EU member states: while $91 \%$ of Germans agree that the burden should be shared, only $46 \%$ of Poles agree (de Vries and Hoffmann, 2016).

The anti-refugee and anti-Muslim attitudes of Poles legitimate Poland's conservative PiS (Law and Justice) government's restrictive politics towards (Muslim) refugees. The redistribution of refugees across the EU was one of the main issues in the 2015 election campaign in Poland, and the newly elected government withdrew, step by step, from Poland's earlier commitment to accept 7000 refugees. On the other hand, the government's protectionist, anti-EU, Islamophobic rhetoric fuels Poles' fears of Islam and Muslims (Hodor and Kosinska, 2016; Tawat, 2016). The Polish media discourse lacks strong alternative positions (Wrzosek, 2016), and Polish activists' and non-governmental organizations' (NGOs) pro-refugee efforts are refused governmental funding. The official rhetoric in Poland is directed explicitly against Germany's 'open door' policy (Funk, 2016). While German reactions to the 'refugee crisis' are uniquely nuanced (Holmes and Castaneda, 2016), it is sufficient to stress here that German citizens were involved in helping refugees, and that a highly publicized 'welcome culture' emerged, although it was countered by anti-refugee voices (Vollmer and Karakayali, 2017).

Poland and Germany thus constitute two quite distinct contexts of solidarity within Europe and with regard to refugees. While Islamophobia is widespread in both countries, Poles clearly reject Muslim refugees and are willing to accept those who are culturally similar, while Germans' attitude towards refugees seems well rooted in cosmopolitan and humanitarian norms. As Polish migrants in Germany maintain regular ties with their 
homeland (Glorius, 2007; Nowicka, 2007), they are exposed to these contradictory discourses, politics and norms of solidarity towards refugees. In this context, it interests us whether it is cultural proximity or a cosmopolitan norm that underlies Polish migrants' obligation to solidarity with refugees.

\section{Survey on Polish migrants' solidarity towards refugees}

In this article, we draw on data from a survey carried out among Polish migrants residing in Germany (BIM, 2017). The survey was conducted in July and August 2016 with the help of a computer-assisted web interview (CAWI).

\section{Design of the study}

We used a vignette experiment survey to measure migrants' perceptions of refugees (Müller et al., 2014; Schachter, 2016). A vignette is a short and carefully constructed description of a person representing a systematic combination of characteristics (Atzmüller and Steiner, 2010; Steiner et al., 2016). As earlier studies among Polish migrants in Germany revealed, ethnic, religious and gender attributes structure migrants' perceptions of other groups (Nowicka and Krzyzowski, 2017); this finding corresponds to the Poles' perceptions of refugees as a symbolic rather than real threat (Hall and Mikulska-Jolles, 2016). Therefore, the vignettes we used in the survey depicted a hypothetical refugee according to the following attributes: a man, woman or family; a Christian or Muslim. Instead of ethnicity/nationality, we used grounds for refugees' seeking asylum in Europe: discrimination, war or severe poverty in their place of origin. Indirectly, these attributes were linked in public discourse in Germany with particular countries: war with Syria, Iraq and Afghanistan; severe poverty with some African countries; (political) discrimination with Algeria, Morocco and Tunisia (Jäger and Wamper, 2017). ${ }^{3}$ A respondent was presented, for example, with the following description: $A$ Muslim woman seeking asylum due to discrimination. ${ }^{4}$ Every description was followed by a question about whether or not the respondent would accept the described person(s) as an inhabitant of the same country (Poland/ Germany), an inhabitant of the same city (in Poland/in Germany), a neighbour (in Poland/in Germany) or friend (in Poland/in Germany). The relationships and locations were randomized.

Vignettes help to elicit participants' automatically generated meanings. Thus vignette surveys are particularly useful in studying attitudes in politicized contexts, such as that of immigration, when respondents, if asked explicitly about their acceptance or rejection of an ethnic group, might prefer to give an answer which they consider 'politically correct' and socially desirable (Bilewicz et al., 2014; Steiner et al., 2016). In our study, each respondent was presented with eight randomly generated vignettes. The respondents could see one vignette at a time (single-profile vignette) instead of a paired profile or multiple profiles frequently used in conjoint surveys (Hainmueller et al., 2015) to avoid the risk that the respondents select the profile which they consider more socially desirable (Steiner et al., 2016). Our earlier study demonstrated that Poles in Germany show a preference for greater levels of social distance from Muslims if asked indirectly, comparing to direct attitudinal statements on Muslims' presumed cultural otherness (Nowicka 
and Krzyzowski, 2017). This demonstrates responsiveness to the perceived social desirability of their answers.

We did not split vignettes into sub-populations because we did not presume any factor (such as gender, religion, reason to seek refuge abroad, destination) to be a strong betweensubjects factor (Steiner et al., 2016); for this same reason, we did not expect interaction effects between the profiles and presented the vignettes subsequently. Additionally, the survey collected the respondents' sociodemographic characteristics and questions relating to such items as: frequency of contact with significant others in Poland; ethnic composition of social networks; information sources on refugees; support for refugees; and attitudes to refugee-related issues present in public discourses in Poland and in Germany. We discussed the results from this part of the survey elsewhere (Nowicka et al., 2019).

\section{Sampling strategy and sample composition}

Real-time sampling (RTS) was used to reach the target population. RTS is a unique method that uses a random selection of cookies tracking visits to particular websites, in our case German IP addresses visiting websites in the Polish language. Due to the limited knowledge of the Polish language among those who are not of Polish origin (European Commission, 2012), this strategy is very effective. These users were shown invitations to the survey in the form of a pop-up window. The sample included 2500 people born in Poland and residing in Germany (controlled by the initial questions in the survey) and was created through probability-based recruiting methods. The size of the sample and the sampling method minimized sample bias.

The average age of the research participants is 43 , and women make up $54 \%$ of the sample. This corresponds with the statistical information on the Polish population in Germany (Zensus, 2011). Half of the respondents declared having a Bachelor's or Master's degree of education, which matches the findings on Polish outgoing migration (Slany and Ślusarczyk, 2013). Most of the respondents (75\%) have settled in Germany permanently, while the rest live in Germany most of the year; $41 \%$ have lived in Germany for over 10 years, and 28\% have German citizenship. The majority (63\%) visit Poland on a regular basis, usually once every six months or more frequently, and $29 \%$ have a household in both Poland and Germany.

\section{Conjoint analysis}

The survey data were analysed with the help of conjoint analysis (CA) (Gustafsson et al., 2003; Rao, 2014). This type of analysis belongs to a broader class of multivariate techniques. CA is extensively used to understand respondents' behavioural choices (especially in urban planning, health research) (Bridges et al., 2011; Makkar et al., 2015). CA is based on a premise that subjects estimate the value (utility) of a real or hypothetical product/behaviour/idea/person by combining the separate amounts of utility provided by single constituent part of a product/service/idea/person (attribute - predictor variable). CA tests combinations of these parts (attributes) to find out respondents' preferences. Thus CA makes it possible to decompose preferences and to estimate the relative importance of each single attribute for overall decision making (Orme, 2014). 
Table I. List of attributes describing an immigrant and their levels.

\begin{tabular}{ll}
\hline Attribute & Attribute levels \\
\hline Refugee's country of stay & Poland \\
& Germany \\
Level of potential closeness/the refugee's relations with & Resident of the same country \\
the respondent & Resident of the same city \\
& Neighbour \\
Division on the basis of gender and religion and a refugee & Friend \\
staying with or without his/her family & Muslim woman \\
& Muslim man \\
& Muslim family \\
& Christian woman \\
Cause of migration & Christian man \\
& Christian family \\
& Extreme poverty and famine \\
& Persecution and discrimination \\
\hline
\end{tabular}

This method of analysis is particularly useful in researching sensitive issues and implicit preferences (Aguinis and Bradley, 2014). In the context of attitudinal research in the field of immigration and ethnicity, though, CA is new, and it should not be confused with survey experiments with conjoint design using vignette pairs or vignette sets (Hainmueller et al., 2015; Schachter, 2016). As our central research question is about the respondents' preference (we ask whom they are more willing to accept as their neighbour, friend, or inhabitant of the same country, respectively), CA was our preferred analytical strategy. It allowed us to answer this question without the risk of receiving a socially more desired answer. Further, CA makes no assumptions about the nature of the relationship between the attributes (in our case gender, location, religion, reason for seeking asylum) and the dependent variable (here: the acceptance of a refugee with a particular profile) and is therefore particularly useful when exploring unknown variables as potential predictor variables (attributes) (Schaupp and Bélanger, 2005).

\section{Results}

We carried out the conjoint analysis on a sample of 2500 respondents using 144 different combinations of refugee descriptions. All attribute levels used in vignettes (refugee profiles) are presented in Table 1. The analysis focused on the impact of selected features and circumstances related to refugees' presence in Germany or in Poland (attributes) on the degree of acceptance of these groups expressed by Poles living in Germany (preference).

The analysis showed that the most important attribute was 'Division on the basis of gender and religion and a refugee staying with or without his/her family', while the least important attribute was 'Refugee's country of stay'. 
Table 2. Presentations of Importance values for all the analysed attributes.

Attribute

Importance values

Division on the basis of gender and faith and staying with or without

$61.86 \%$

a family

Level of closeness/relations between the immigrant and respondent

$33.26 \%$

Cause of migration

$3.51 \%$

The refugee's country of stay

$1.37 \%$

Importances (expressed as a percentage) are used in the CA as parameters that reveal the strength of a given attribute's influence, in relation to the other attributes (Rao, 2014), on the acceptance/non-acceptance of a refugee. The relative Importance scores for each attribute are presented in Table 2.

On the basis of the Importance parameter, we can draw the conclusion that the attributes gender, religion, and whether a person is staying with or without family have double the amount of influence on a respondent's decision to accept or not accept a refugee than the degree of closeness/relations between the refugee and respondent. An even greater difference in the influence on a research participant's assessment occurs between the most important attribute and the two remaining attributes, namely the cause of migration and the refugee's hypothetical country of stay, whereby the influence of the most important attribute is more than 15 and 45 times greater, respectively.

In order to check which of the attribute levels is most important ${ }^{5}$ and how they influenced the research participants' decisions, we conducted an analysis of the utility scores within one attribute level. A comprehensive list of all the utility scores for all the analysed attribute levels is presented in Table 3.

CA measures utility on interval scales: when comparing two attribute levels, we cannot state that one of them is twice as desirable, only that it is more desirable to the tune of 20 utility points. Since the point of reference is arbitrary (hypothetical, and in our study set to zero), we cannot compare numerical utility values between attributes, only increases and decreases in assessment values when the levels of different attributes are changing. Below is the discussion of a full analysis of the attributes' utilities.

\section{Gender, religion and family status}

On the basis of the analysis of utility scores, we can conclude that when a refugee was described as a male follower of Islam, the respondents expressed a greater reluctance to accept his stay. A Muslim family and Muslim woman were ranked second and third, respectively. The three descriptions that exerted the largest positive influence on a decision to accept an immigrant were those relating to refugees professing to be Christian. The descriptions that were most willingly accepted were, in descending order, Christian woman, Christian man, and Christian family. It is worth noting that the descriptions of Christians are essentially similar to each other with regard to their utility values. In other words, these values do not greatly differ from each other, as was the case with the description of followers of Islam. It therefore is legitimate to conclude that, in the first group, 
Table 3. A comprehensive list of the utility values for all the attribute levels ${ }^{a}$.

\begin{tabular}{llrl}
\hline Attribute & Attribute levels & Utility estimates & Standard error \\
\hline Division on the basis of & Muslim woman & -0.0201 & 0.0013 \\
gender and religion, and & Muslim man & 0.0386 & 0.0013 \\
staying with or without & Muslim family & -0.0579 & 0.0013 \\
family & Christian woman & 0.0426 & 0.0013 \\
& Christian man & 0.0391 & 0.0013 \\
& Christian family & -0.0423 & 0.0013 \\
Level of closeness/ & Resident of the same country & 0.0203 & 0.0010 \\
relations between & Resident of the same city & 0.0156 & 0.0010 \\
the immigrant and & Neighbour & -0.0022 & 0.0010 \\
respondent & Friend & -0.0337 & 0.0010 \\
Cause of migration & Extreme poverty and famine & -0.0007 & 0.0008 \\
& Persecution and discrimination & 0.0032 & 0.0008 \\
The refugee's country & Prmed conflict & -0.0025 & 0.0008 \\
of stay & Poland & -0.0011 & 0.0006 \\
\hline
\end{tabular}

${ }^{a}$ Vignettes presented to respondents were in Polish. Polish nouns are never gender neutral but suggest male or female gender if a noun relates to a profession or person's origin. In English thus, we translate the word 'Muzułmanka' to 'Muslim woman' and 'Muzułmanin' to 'Muslim man'.

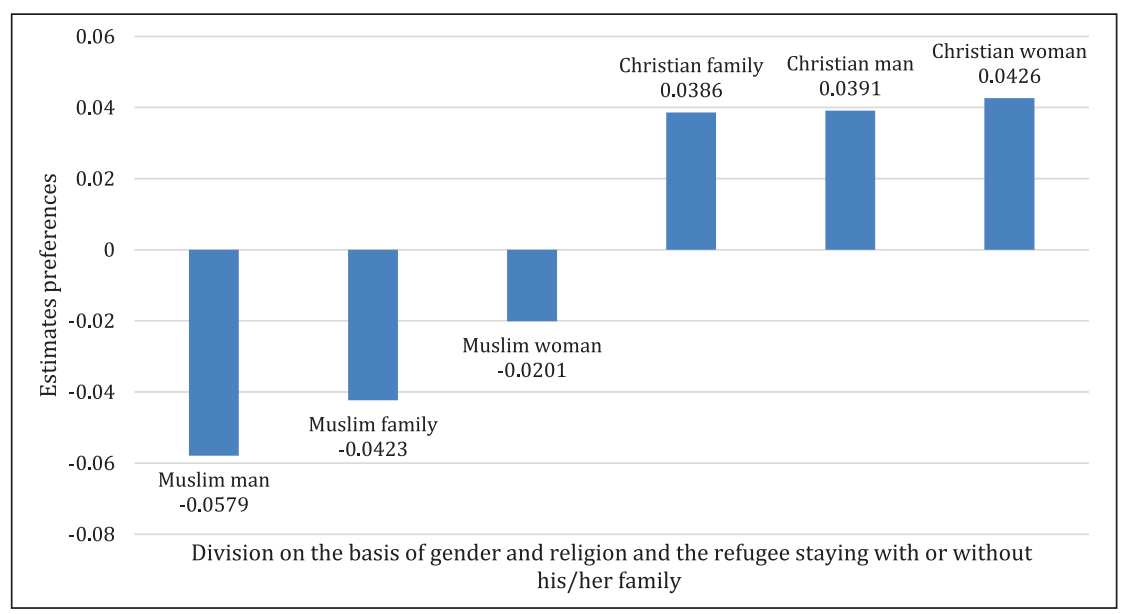

Figure I. Distribution of utilities for the attribute 'Division on the basis of gender and religion and the refugee staying with or without his/her family'.

acceptance or lack of acceptance is determined by the professed religion itself, while, within this group, other much more significant factors are gender and whether a person is staying with or without a family. The difference in utilities between the lowest value and the highest is $0.0426-(-0.0579)=0.1005$, which amounts to $61.86 \%$ of the influence of all the attributes determining acceptance or non-acceptance of a refugee (Figure 1). 


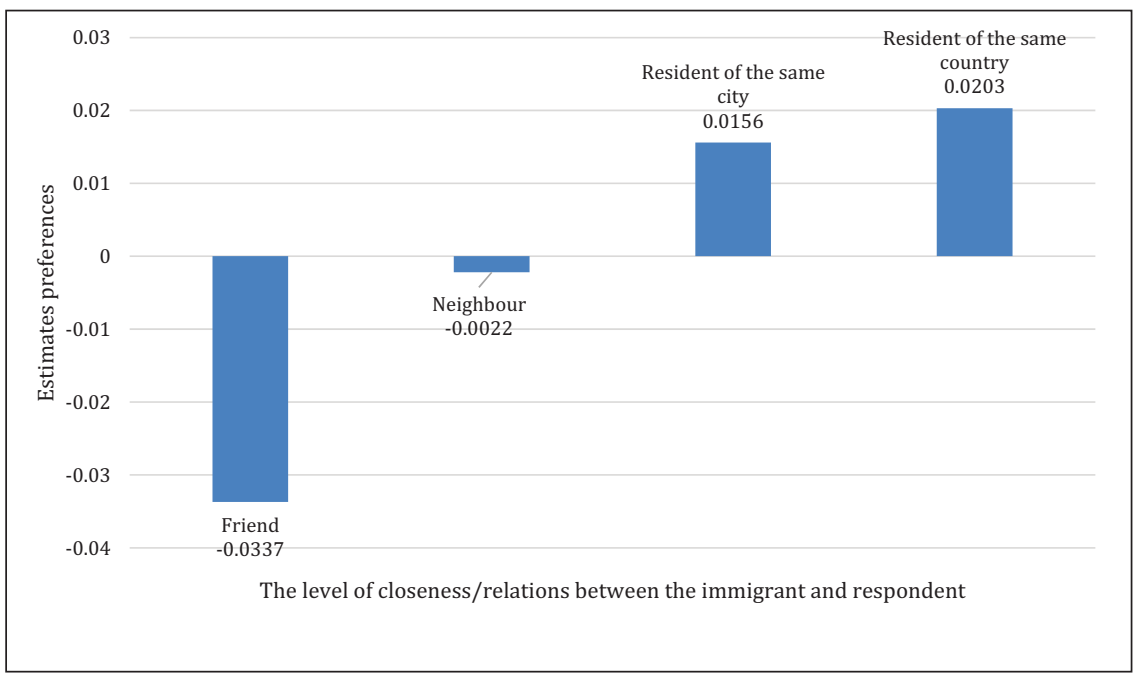

Figure 2. Distribution of utilities for the attribute 'Level of closeness/relations between the refugee and respondent'.

\section{Proximity between the immigrant and respondent}

On the basis of the analysis of utilities, we can conclude that the lower the level of potential closeness between a refugee and the research participant, the greater the tendency among respondents to accept him or her. In particular, the suggestion that the refugee could well be the respondent's friend lowered a respondent's tendency to accept his/her stay. The difference in utilities between the two descriptions is $0.0203-(-0.0337)=$ 0.0540 , which amounts to $33.26 \%$ of the influence of all the attributes on whether or not an immigrant is accepted. The distribution of utilities for this attribute is presented in Figure 2 .

\section{Cause of seeking refuge}

On the basis of the analysis of utility values, we can conclude that escaping persecution and discrimination were one reason that caused the study participants to be more willing to accept a refugee. The least compelling pro-acceptance argument for study participants was military conflict, while the extreme poverty and hunger reason scored between the two aforementioned reasons. The difference in the utilities between the two descriptions amounts to $0.0032-(-0.0025)=0.0057$, which constitutes $3.51 \%$ of the influence of the attributes on whether or not a refugee was accepted. A distribution of utilities for this attribute is presented in Figure 3.

\section{The refugee's country of stay}

Based on the analysis of utility values, we can conclude that when a refugee was being described as potentially residing in Poland, the respondents expressed greater reluctance 


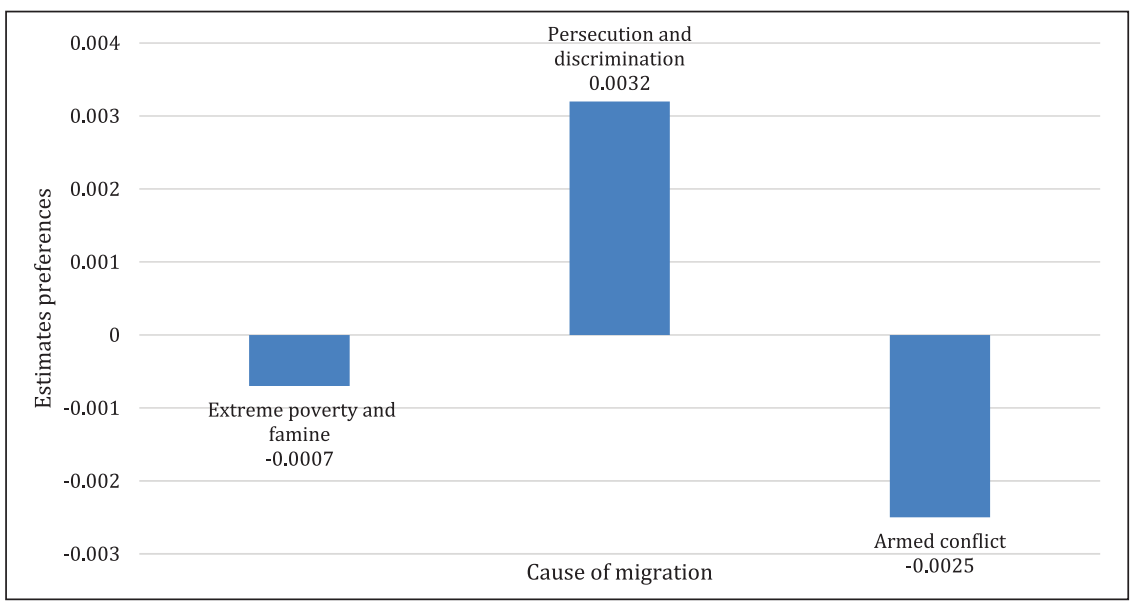

Figure 3. Breakdown of utilities for the attribute 'Cause of seeking refuge'.

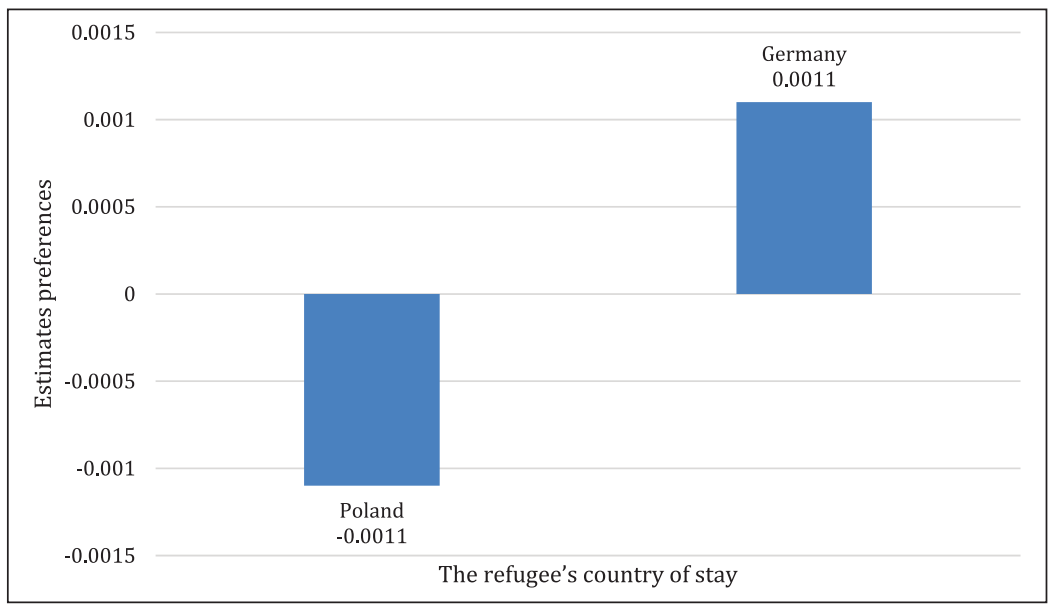

Figure 4. Breakdown of utilities for the attribute 'Immigrant's country of stay'.

to accept his/her stay there than in the case when he or she was described as residing in Germany. The difference in utilities between the two descriptions constituted 0.002 , which amounts to $1.3 \%$ of the influence of all the attributes on whether or not an immigrant was accepted. The distribution of utilities for this attribute is presented in Figure 4.

\section{Discussion}

In order to make sense of these results, we use the heuristic framework of the boundarymaking paradigm which considers group identity formation as a dialectical process between minority and majority groups (Lamont and Molnár, 2002; Wimmer, 2008). 
Accordingly, boundaries are processual in the sense of their constant making and unmaking. Boundaries are multidimensional and mutable across time and space: while religion might be an extremely silent boundary in some countries, elements such as race, language or culture can be largely relevant in others (Bail, 2008). It is thus possible for us to capture the particular constellation of boundaries at a particular moment in time. Given the multidimensional character of Islamophobia (Helbling, 2017), boundary-making is the heuristic framework of choice. Further, Alba (2005) distinguishes two kinds of boundaries - bright and blurred. Bright boundaries imply an unambiguous definition of belonging to a group but also unbridgeable differences between the groups; on the contrary, blurred boundaries suggest inclusion of others, and adaptation of and changes to group identities. With the decline of their own perceived ethnic identity in the course of assimilating with the majority, migrants might turn against other migrants in order to maintain positions in the host society earned at great cost (Alba, 2005; Wimmer, 2009). Migrants may thus attempt to establish a bright boundary towards new groups, while at the same time blurring the boundary between themselves and the majority (Alba, 2005; Senay, 2017). ${ }^{6}$

Our analysis allowed us to distinguish four attributes on the basis of which the studied migrants produce a boundary between their own group and the outgroups. Out of the four attributes, religion - specifically Islam and Christianity in the case at hand - turns out to be the most powerful boundary. Gender is an important factor that modifies the principle of boundary-making, but only when issues related to gender intersect with religion. Thus, gender matters only if a refugee is Muslim, but not when he or she is Christian. In particular, respondents are more likely to deny male Muslims the right to stay in Europe, which corresponds with public narratives about male Muslims as 'dangerous others' (Bertram and Jędrzejek, 2015; Mythen et al., 2009; Razack, 2004).

Our analysis shows that religion as a boundary is significant irrespective of the migrants' sense of belonging to their country of origin (Poland) or residence (Germany). Accordingly, the respondents are equally willing to accept Christian refugees in Poland and in Germany, and to refuse to accept Muslim refugees either in Poland or Germany. These results seem to confirm the diagnoses that the new alliances within Europe rely on boundary-making against Islam, that is, Muslims, personified by recent refugees. Thus, boundary-making in reference to disparate values that results in stronger group identities (Phalet et al., 2013; Wimmer, 2008) seems to be a powerful mechanism that re-establishes the sense of (exclusionary) solidarity (Allen, 1999).

As some studies prove, ethnicized Islamophobia as an element of 'identity politics' can coexist with sub-national or regional separatism (Dietz, 2004) or facilitate the rise of transnational linkages between nationally organized right-wing parties and movements (Berntzen and Weisskircher, 2016; Langenbacher, 2011). By studying migrants and their attitudes instead of social movements or political parties, we learn how Islamophobia as an everyday project (Vieten and Poynting, 2016) is crossing national boundaries of loyalty and becoming a European transnational exclusionary project.

Three aspects require further attention. First, some research suggests that Islamophobia as an exclusionary project should not be mistaken for a pro-Christian attitude (Czymara and Schmidt-Catran, 2016; Stefaniak et al., 2015), although religious particularism is a strong predictor of prejudice against ethnic others (Scheepers et al., 2002), in particular 
if racial/ethnic and religious boundaries are coextensive (Yamane and Roberts, 2012). These studies suggest that the respondents are less inclined to solidarity with refugees due to their fear of Muslim immigrants rather than because of feeling solidarity with Christians or rejecting Islam as a religion (see also Helbling, 2017), yet this hypothesis requires further empirical verification. Second, the Christian religious orientation is not necessarily at odds with people's commitment to universal human rights and to a solidarity rooted in the cosmopolitan obligation towards others, including other religious groups (Lohmann, 2016). In turn, it possibly does not matter if Poles in Germany are less religious than Poles in Poland but more religious than Germans (Röder and Lubbers, 2015), yet this hypothesis also requires empirical verification. Third, Islamophobia overlaps with other particularisms (e.g. class, ethnicity, gender), but it also bears universal characteristics that potentially bridge other modes of exclusion. Our results suggest that it is more powerful than national boundaries of solidarity; yet it requires further investigation whether Islamophobia could (irrespective of the normative problem of whether it should) indeed become a durable and stable source of European solidarity.

\section{Authors's note}

Lukasz Krzyzowski is also affiliated with University of Western Australia, Australia and Magdalena Nowicka is also affiliated with DeZIM e.V., Germany.

\section{Funding}

The author(s) disclosed receipt of the following financial support for the research, authorship, and/ or publication of this article: This publication was made possible thanks to the financial support of the Federal Government Commissioner for Migration, Refugees and Integration granted for the research-intervention cluster 'Solidarität im Wandel?' ('Solidarity in Transition?') at the Berlin Institute for Integration and Migration Research (BIM) at the Humboldt-Universität zu Berlin, as well as the Mobility Plus Fellowship awareded by The Ministry of Science and Higher Education in Poland to Lukasz Krzyzowski.

\section{Notes}

1. The Visegrad Group is an alliance of the Czech Republic, Hungary, Poland and Slovakia. The Three Sees Initiative consists of the following 12 countries: Poland, Hungary, Czech Republic, Slovakia, Romania, Bulgaria, Lithuania, Estonia, Latvia, Croatia, Slovenia and Austria.

2. Germany was among the countries most exposed to the 'refugee crisis', with more than a million asylum seekers registered in 2015 and 2016 (a third of all applicants in the EU), while Poland registered 10,255 asylum seekers, with the majority coming from Russia, Ukraine, Tajikistan, Georgia, Armenia and Chechnya (Eurostat, 2016). The number of Christians among refugees is unclear; some Christians converted to Islam in Syria; some Muslims convert to Christianity in Europe; finally, some Christians in refugee shelters do not reveal their religious belonging for fear of repercussions from Muslim refugees (OpenDoors, 2016).

3. A similar discourse on persecution for political beliefs was absent from the Polish public space (Wrzosek, 2016).

4. The variables in bold were randomly assigned.

5. If all attributes are equally important (have an equal utility), CA speaks of a null hypothesis. Thus, CA tests the null hypothesis in the aggregate decision model by determining deviation 
from the zero, in preference of a choice (positive value of utility estimate) or against it (negative value of utility estimate).

6. This process may be associated with ethnic competition or cultural adoption; it is beyond the scope of this article to elaborate on this debate.

\section{References}

Aguinis, H. and K.J. Bradley (2014) 'Best Practice Recommendations for Designing and Implementing Experimental Vignette Methodology Studies', Organizational Research Methods 17(4): 351-71.

Alba, R. (2005) 'Bright vs. Blurred Boundaries: Second-generation Assimilation and Exclusion in France, Germany, and the United States', Ethnic and Racial Studies 28(1): 20-49.

Alexander, J.C. (2014) 'Morality as a Cultural System: On Solidarity Civil and Uncivil', pp. 30310 in V. Jeffries (ed.) The Palgrave Handbook of Altruism, Morality, and Social Solidarity. New York: Palgrave Macmillan.

Allen, A. (1999) 'Solidarity after Identity Politics: Hannah Arendt and the Power of Feminist Theory', Philosophy \& Social Criticism 25(1): 97-118.

Allen, C. (2010) Islamophobia. Farnham: Ashgate.

Ariely, G. (2014) 'Does Diversity Erode Social Cohesion? Conceptual and Methodological Issues', Political Studies 62(3): 573-95.

Atzmüller, C. and P.M. Steiner (2010) 'Experimental Vignette Studies in Survey Research', Methodology 6(3): 128-38.

Bail, C.A. (2008) 'The Configuration of Symbolic Boundaries against Immigrants in Europe', American Sociological Review 73: 37-59.

Balibar, E. (1991) 'Is There a "Neo-racism”?', pp. 17-28 in E. Balibar and I.M. Wallerstein (eds) Race, Nation, Class: Ambiguous Identities. London: Verso.

Ban Ki-moon (2016) 'Refugee Crisis about Solidarity, Not Just Numbers, Secretary-General Says at Event on Global Displacement Challenge', press release, 15 April, New York, URL (consulted 13 January 2020): http://www.un.org/press/en/2016/sgsm17670.doc.htm

Bansak, K., J. Hainmueller and D. Hangartner (2016) 'How Economic, Humanitarian, and Religious Concerns Shape European Attitudes toward Asylum Seekers', Science 354(6309): $217-22$.

Banting, K.G. and W. Kymlicka (2017) The Strains of Commitment: The Political Sources of Solidarity in Diverse Societies. Oxford: Oxford University Press.

Baurmann, M. (1999) 'Solidarity as a Social Norm and as a Constitutional Norm', pp. 243-72 in B. Bayertz (ed.) Solidarity. Dordrecht: Springer Science+Business Media.

Bayrakli, E. and F. Hafez (eds) (2016) European Islamophobia Report, 2015. Washington, DC: SETA.

Berntzen, L.E. and M. Weisskircher (2016) 'Anti-Islamic PEGIDA Beyond Germany: Explaining Differences in Mobilisation', Journal of Intercultural Studies 37(6): 556-73.

Bertram, Ł. and M. Jędrzejek (2015) Islamskie hordy, azjatycki najazd, socjalny dżihad: Jak polskie media piszq o uchodźcach? URL (consulted 14 October 2016): http://obserwatorium. kulturaliberalna.pl/raport/islamskie-hordy-azjatycki-najazd-socjalny-dzihad-jak-polskiemedia-pisza-o-uchodzcach-uchodzcy/

Bhabha, H. (1996) The Location of Culture. London: Routledge.

Bielefeld, H. (2010) 'Das Islambild in Deutschland: Zum Öffentlichen Umgang mit der Angst vor dem Islam', pp. 173-206 in T.G. Schneiders (ed.) Islamfeindlichkeit. Wenn die Grenzen der Kritik verschwimmen. Wiesbaden: VS Verl. für Sozialwissenschaften.

Bilewicz, M., M. Marchlewska, W. Soral and M. Winiewski (eds) (2014) Mowa nienawiści: Raport z badań sondażowych. Warszawa: Fundacja im. Stefana Batorego. 
BIM (Berliner Institut für empirische Integrations-und Migrationsforschung) (2017) Solidarität im Wandel? (Solidarity in Change?), research report. Berlin: Humboldt-Universität zu Berlin.

Blokker, P. and G. Delanty (2010) 'European Identity, Post-Western Europe, and Complex Cultural Diversity', pp. 117-34 in C.S. Browning and M. Lehti (eds) The Struggle for the West: A Divided and Contested Legacy. Abingdon, Oxon: Routledge.

Bridges, J.F.P., A.B. Hauber, D. Marshall, A. Lloyd, L.A. Prosser, D.A. Regier, et al. (2011) 'Conjoint Analysis Applications in Health - A Checklist. A Report of the ISPOR Good Research Practices for Conjoint Analysis Task Force', Value in Health: The Journal of the International Society for Pharmacoeconomics and Outcomes Research 14(4): 403-13.

Buchowski, M. (2016) 'Making Anthropology Matter in the Heyday of Islamophobia and the "Refugee Crisis": The Case of Poland', Český lid 103(1).

Çakir, N. (2016) 'PEGIDA: Islamfeindlichkeit aus der Mitte der Gesellschaft', pp. 149-62 in A. Häusler (ed.) Die Alternative für Deutschland. Wiesbaden: Springer.

Calhoun, C. (1999) 'Nationalism, Political Community and the Represention of Society, Or, Why Feeling at Home is not a Substitute for Public Space', European Journal of Social Theory 2(2): 217-31.

Castano, E. (2004) 'European Identity: A Social-psychological Perspective', pp. 40-58 in R.K. Herrmann, T. Risse-Kappen and M.B. Brewer (eds) Transnational Identities: Becoming European in the EU. Lanham, MD: Rowman and Littlefield.

CBOS (2016) Stosunek do przyjmowania uchodźców w Polsce $i$ w Czechach. Komunikat z badań $\mathrm{Nr}$ 54/2016. URL (consulted 17 February 2019): http://www.cbos.pl/SPISKOM. POL/2016/K_054_16.pdf

Creutz-Kämppi, K. (2008) 'The Othering of Islam in a European Context', Nordicom Review 29(2): 295-308.

Czymara, C.S. and A.W. Schmidt-Catran (2016) 'Wer ist in Deutschland willkommen?', KZfSS Kölner Zeitschrift für Soziologie und Sozialpsychologie 68(2): 193-227.

Decker, O., J. Kiess and E. Brähler (eds) (2016) Die enthemmte Mitte. Autoritäre und rechsextreme Einstellung in Deutschland. Gießen: Psychosozial-Verlag.

Delanty, G. (1995) Inventing Europe. London: Palgrave Macmillan UK.

Delanty, G. (2007) 'Europeanization and Democracy: The Question of Cultural Identity', pp. 77-93 in J. DeBardeleben and A. Hurrelmann (eds) Democratic Dilemmas of Multilevel Governance: Legitimacy, Representation and Accountability in the European Union. New York: Palgrave Macmillan.

Dietz, G. (2004) 'Frontier Hybridisation or Culture Clash? Transnational Migrant Communities and Sub-national Identity Politics in Andalusia, Spain', Journal of Ethnic and Migration Studies 30(6): 1087-112.

Diez, T. (2010) 'Europe's Others and the Return of Geopolitics', Cambridge Review of International Affairs 17(2): 319-35.

Durkheim, É. (1997) The Division of Labor in Society. New York: The Free Press.

El-Tayeb, F. (2011) European Others: Queering Ethnicity in Postnational Europe. Minneapolis, MN: University of Minnesota Press.

European Commission (2012) Special Eurobarometer 386: Europeans and Their Languages. URL (consulted 12 November 2016): http://ec.europa.eu/public_opinion/archives/ebs/ebs 386 en.pdf

Eurostat (2016) 'Asylum in the EU Member States', Eurostat News Release 44.

Funk, N. (2016) 'A Spectre in Germany: Refugees, a "Welcome Culture" and an "Integration Politics", Journal of Global Ethics 12(3): 289-99. 
Gerhards, J., S. Hans and J. Schupp (2016) Einstellungen der BürgerInnen in Deutschland zur Aufnahme von Geflüchteten. DIW Wochenbericht 21, DIW, URL (consulted 20 February 2019): https:/www.diw.de/documents/publikationen/73/diw_01.c.534432.de/16-21-1.pdf

Glorius, B. (2007) Transnationale Perspektiven. Eine Studie zur Migration zwischen Polen und Deutschland. Bielefeld: transcript Verlag.

Górak-Sosnowska, K. (2016) 'Islamophobia without Muslims? The Case of Poland', Journal of Muslims in Europe 5(2): 190-204.

Gould, C.C. (2011) 'Do Cosmopolitan Ethics and Cosmopolitan Democracy Imply Each Other?', in S. van Hooft and W. Vandekerckhove (eds) Questioning Cosmopolitanism. Berlin: Springer, pp. 153-66.

Gustafsson, A., A. Herrmann and F. Huber (eds) (2003) Conjoint Measurement: Methods and Applications. Berlin: Springer.

Hainmueller, J., D. Hangartner and T. Yamamoto (2015) 'Validating Vignette and Conjoint Survey Experiments against Real-world Behaviour', Proceedings of the National Academy of Sciences of the United States of America 112(8): 2395-400.

Hall, D. and A. Mikulska-Jolles (2016) Uprzedzenia, strach czy niewiedza? Młodzi Polacy o powodach niechęci do przyjmowania uchodźców. Warszawa. URL (consulted 1 March 2019): https://interwencjaprawna.pl/docs/ARE-116-uprzedzenia-mlodych-polakow.pdf

Hall, S. (1996) 'Who Needs "Identity”?', pp. 1-17 in S. Hall and P. du Gay (eds) Questions of Cultural Identity. London: Sage.

Helbling, M. (2017) 'What Is Islamophobia? Disentangling Citizens Feelings Towards Ethnicity, Religion and Religiosity Using a Survey Experiment', SSRN Electronic Journal.

Hodor, K. and A. Kosinska (2016) 'Polish Perceptions on the Immigration Influx: A Critical Analysis', University of Bologna Law Review 1(2): 242-70.

Holmes, S.M. and H. Castaneda (2016) 'Representing the "European Refugee Crisis" in Germany and Beyond: Deservingness and Difference, Life and Death', American Ethnologist 43(1): 12-24.

Ipsos Mori (2014) Perils of Perception Survey. URL (consulted 1 March 2019): https://www. ipsos-mori.com/researchpublications/researcharchive/3466/Perceptions-are-not-realityThings-the-world-gets-wrong.aspx

Jäger, M. and R. Wamper (2017) Von der Willkommenskultur zur Notstandsstimmung. Der Fluchtdiskurs in deutschen Medien 2015 und 2016. Duisburg: Duisburger Institut für Sprachund Sozialforschung.

Klug, P. (2010) Feindbild Islam? Der Diskurs über Muslime in Bundestagsdebatten vor und nach dem 11. September. Marburg: Tectum.

Kymlicka, W. (2015) 'Solidarity in Diverse Societies: Beyond Neoliberal Multiculturalism and Welfare Chauvinism', Comparative Migration Studies 3(1): 1-19.

Lamont, M. and V. Molnár (2002) 'The Study of Boundaries in the Social Sciences', Annual Review of Sociology 28(1): 167-95.

Langenbacher, N. (2011) Is Europe on the "Right" Path? Right-wing Extremism and Right-wing Populism in Europe. Berlin: Friedrich-Ebert-Stiftung, Forum Berlin.

Lohmann, F. (2016) 'Human Rights Between Universalism and Religious Particularism', pp. 45-55 in M.L. Pirner, J. Lähnemann and H. Bielefeldt (eds) Human Rights and Religion in Educational Contexts. Zürich: Springer.

Makkar, S.R., A. Williamson, T. Turner, S. Redman and J. Louviere (2015) 'Using Conjoint Analysis to Develop a System to Score Research Engagement Actions by Health Decision Makers', Health Research Policy and Systems 13: 22.

Müller, T., P. Heström, S. Valdez and K. Wennberg (2014) Right-wing Populism and Social Distance towards Muslims in Sweden - Results from a Nation-wide Vignette Study. Linköping: 
Linköping University, Institute for Analytical Sociology, URL (consulted 2 March 2019): http://www.diva-portal.org/smash/get/diva2:778393/FULLTEXT02.pdf

Münch, R. (2012) Inclusion and Exclusion in the Liberal Competition State: The Cult of the Individual. London: Routledge.

Mythen, G., S. Walklate and F. Khan (2009) “'I'm a Muslim, but I'm Not a Terrorist”: Victimization, Risky Identities and the Performance of Safety', British Journal of Criminology 49(6): 736-54.

Narkowicz, K. and K. Pędziwiatr (2017) 'From 'Unproblematic to Contentious: Mosques in Poland', Journal of Ethnic and Migration Studies 43(3): 1-17.

Nowicka, M. (ed.) (2007) Von Polen nach Deutschland und zurück. Die Arbeitsmigration und ihre Herausforderungen für Europa. Bielefeld: transcript Verlag.

Nowicka, M. and Ł. Krzyzowski (2017) 'The Social Distance of Poles to Other Minorities: A Study of Four Cities in Germany and Britain', Journal of Ethnic and Migration Studies 43(3): 359-78.

Nowicka, M., Ł. Krzyzowski and D. Ohm (2017) Solidarisierung in Europa. Migrant*innen und Osteuropäer*innen und deren Engagement für Geflüchtete. In: Berliner Institut für empirische Integrations- und Migrationsforschung (BIM) Solidarität im Wandel? (Solidarity in Change), research report. Berlin: Humboldt-Universität zu Berlin, pp. 10-30, URL (consulted 15 January 2020): https://www.integrationsbeauftragte.de/resource/blob/72490/316492/4752a5 27c9d904ff4ee5834e75867014/forschung-bim-solidaritaet-data.pdf

Nowicka, M., Ł. Krzyzowski and D. Ohm (2019) 'Transnational Solidarity, the Refugees and Open Societies in Europe', Current Sociology 67(3): 383-400.

Oosterlynck, S., M. Loopmans, N. Schuermans, J. Vandenabeele and S. Zemni (2016) 'Putting Flesh to the Bone: Looking for Solidarity in Diversity, Here and Now', Ethnic and Racial Studies 39(5): 764-82.

OpenDoors (2016) Attacks on Christian Refugees: A Documentation. Kelkheim, URL (consulted 8 March 2019): https://www.opendoors.de/sites/default/files/2017_July_Refugee_Report_ Rotenburg_English.pdf.

Orme, B.K. (2014) Getting Started with Conjoint Analysis: Strategies for Product Design and Pricing Research. Glendale, CA: Research Publ.

Pensky, M. (2000) 'Cosmopolitanism and the Solidarity Problem: Habermas on National and Cultural Identities', Constellations 7(1): 64-79.

Phalet, K., M. Maliepaard, F. Fleischmann and D. Güngör (2013) 'The Making and Unmaking of Religious Boundaries', Comparative Migration Studies 1(1): 123-45.

Pickel, G. and C. Öztürk (2018) 'Islamophobia without Muslims? The "Contact Hypothesis" as an Explanation for Anti-Muslim Attitudes - Eastern European Societies in a Comparative Perspective', Journal of Nationalism, Memory \& Language Politics 12(2): 162-91.

Rao, V.R. (2014) Applied Conjoint Analysis. Berlin: Springer.

Razack, S.H. (2004) 'Imperilled Muslim Women, Dangerous Muslim Men and Civilised Europeans: Legal and Social Responses to Forced Marriages', Feminist Legal Studies 12(2): 129-74.

Röder, A. and M. Lubbers (2015) 'Attitudes towards Homosexuality amongst Recent Polish Migrants in Western Europe: Migrant Selectivity and Attitude Change', Journal of Ethnic and Migration Studies 41(11): 1858-84.

Ruf, W. (2012) Der Islam. Schrecken des Abendlands; wie sich der Westen sein Feindbild konstruiert. Köln: PapyRossa-Verl.

Runnymede Trust (1997) Islamophobia: A Challenge for Us All. London: Runnymede Trust.

Said, E.W. (2003) Orientalism. New York: Vintage Books.

Schachter, A. (2016) 'From "Different" to "Similar", American Sociological Review 81(5): 9811013. 
Schaupp, L.C. and F. Bélanger (2005) 'A Conjoint Analysis of Online Consumer Satisfaction', Journal of Electronic Commerce Research 6(2): 95-111.

Scheepers, P., M. Gijsberts and M. Coenders (2002) 'Ethnic Exclusionism in European Countries: Public Opposition to Civil Rights for Legal Migrants as a Response to Perceived Ethnic Threat', European Sociological Review 18(1): 17-34.

Semati, M. (2010) 'Islamophobia, Culture and Race in the Age of Empire', Cultural Studies 24(2): 256-75.

Senay, B. (2017) Instrumentalising the Influx of Refugees for Boundary-Change? The Turkish Community in the Pursuit of Social Acceptance in Germany. Working Paper 91. Sussex: Sussex Centre for Migration Research.

Slany, K. and M. Ślusarczyk (2013) Migracje zagraniczne Polakow w swietle NSP 2011. Trendy i charakterystyki socjodemograficzne, URL (consulted 5 March 2019): http://www.euroemigranci.pl/dokumenty/pokonferencyjna/Slany_Slusarczyk.pdf

Stefaniak, A., M. Bilewicz and M. Winiewski (eds) (2015) Uprzedzenia w Polsce. Warsaw: Uniwersytet Warszawski, URL (consulted 29 October 2015): http://cbu.psychologia.pl/ uploads/materialy/Uprzedzenia2015.pdf

Steiner, P.M., C. Atzmüller and D. Su (2016) 'Designing Valid and Reliable Vignette Experiments for Survey Research: A Case Study on the Fair Gender Income Gap', Journal of Methods and Measurement in the Social Sciences 7(2): 52-94.

Stichs, A. (2016) Wie viele Muslime leben in Deutschland? Nürnberg: BAMF.

Strabac, Z., T. Aalberg and M. Valenta (2013) 'Attitudes towards Muslim Immigrants: Evidence from Survey Experiments across Four Countries', Journal of Ethnic and Migration Studies 40(1): 100-18.

Tausch, A. (2016) 'Muslim Immigration Continues to Divide Europe: A Quantitative Analysis of European Social Survey Data', Middle East Review of International Affairs 20(2): $37-50$.

Tawat, M. (2016) 'Towards an Ever "Closer" Union? Refugee Policy and Social Cohesion in Eastern EU Member States', East European Politics 32(2): 277-84.

Tiryakian, E.A. (2005) 'Durkheim, Solidarity, and September 11', pp. 305-21 in J.C. Alexander and P. Smith (eds) The Cambridge Companion to Durkheim. Cambridge: Cambridge University Press.

Vasta, E. (2010) 'The Controllability of Difference: Social Cohesion and the New Politics of Solidarity', Ethnicities 10(4): 503-21.

Vieten, U.M. and S. Poynting (2016) 'Contemporary Far-right Racist Populism in Europe', Journal of Intercultural Studies 37(6): 533-40.

de Vries, C. and I. Hoffmann (2016) Border Protection and Freedom of Movement: What People Expect of European Asylum and Migration Policies. Gütersloh: Bertelsmann Stiftung.

Vollmer, B. and S. Karakayali (2017) 'The Volatility of the Discourse on Refugees in Germany', Journal of Immigrant \& Refugee Studies 29(3): 1-22.

Waldinger, R.D. (2015) The Cross-border Connection: Immigrants, Emigrants, and Their Homelands. Cambridge, MA: Harvard University Press.

Wimmer, A. (2008) 'The Making and Unmaking of Ethnic Boundaries: A Multilevel Process Theory', American Journal of Sociology 113(4): 970-1022.

Wimmer, A. (2009) 'Herder's Heritage and the Boundary-making Approach: Studying Ethnicity in Immigrant Societies', Sociological Theory 27(3): 244-70.

Wintle, M. (2016) 'Islam as Europe's “Other” in the Long Term: Some Discontinuities', History 101(344): 42-61.

Wrzosek, T. (2016) 'Dyskurs o Uchodźcach jako Symptom Kryzysu Solidarności', Journal of Modern Science 1(28): 411-30. 
Yamane, D.A. and K.A. Roberts (eds) (2012) Religion in Sociological Perspective. Los Angeles: Sage.

Younes, A.-E. (2016) 'Islamophobia in Germany: National Report 2015', in E. Bayrakli and F. Hafez (eds) European Islamophobia Report 2015. Washington, DC: SETA.

Zensus (2011) Zensusdatenbank Zensus 2011, URL (consulted 18 October 2015): https://ergebnisse.zensus2011.de/

Zick, A., A. Hövermann and B. Küpper (2011) Intolerance, Prejudice and Discrimination: A European Report, Friedrich-Ebert-Stiftung. Berlin: Forum Berlin.

Zick, A. and A. Klein (2014) Fragile Mitte - feindselige Zustände. Rechtsextreme Einstellungen in Deutschland 2014. Bonn: Dietz.

\section{Author biographies}

Lukasz Krzyzowski is an assistant professor at AGH University of Science and Technology in Kraków, Poland and visiting postdoctoral researcher at the University of Western Australia. His research interests are transnational migration, old age and aged care, STS, intergenerational solidarity, social networks and mixed-methods research.

Magdalena Nowicka is professor for Migration and Transnationalism at the Institute of Social Sciences and research coordinator at the Berlin Institute for Integration and Migration Research (BIM) at Humboldt-Universität zu Berlin. Her research interests include sociology of migration, transnational processes, general social theory and qualitative research methods. 